\title{
An examination of the relationship between competences and wages of higher education graduates: Evidence from Morocco*
}

\author{
Abdellah Abaida, Youssef Lakrari, and Abdeljabbar Abdouni**
}

doi: http://dx.doi.org/10.18543/tjhe-5(1)-2017pp75-100

\begin{abstract}
To provide research insights in line with the Tuning project approach, we estimate the effects of competences on wages of higher education graduates with work experience. Using the conventional earnings regressions methods (Mincer equation) on data from a survey of graduates, we investigate the way in which the labour market reacts and rewards competences. The results show small significant evidence for an effect of competences on wages in our dataset; however, methodological and social skills display positive payoff returns. Our empirical findings also suggest that the labour market rewards less specialised competences, and unlikely methodological and social competences are deemed more necessary compared to cognitive skills (theoretical knowledge). Finally, wages tend to decrease for those who are female and working in the private sector. Overall, the findings of the study are highly related to the specification and structure of the Moroccan labour markets.
\end{abstract}

Acknowledgements: We are grateful for the valuable help from Ahmed Nejmeddine, President of University Hassan I, for funding the survey on graduates with the collaboration of the Superior Council of Higher Education. This paper was presented at the Second Symposium of the 4th Tuning General Meeting, Johannesburg, April 03-06, 2017. We acknowledge helpful assistance from Maria Ortiz and Pablo Beneitone, and we thank Damtew Teferra and participants for very insightful comments. This paper was written as part of the application for a research visit to Tuning Academy at the University of Deusto. The views expressed in this paper are those of the authors alone, and any of the remaining errors are the authors' responsibility.

** Abdellah Abaida (a.abaida@uhp.ac.ma) is a PhD candidate in applied economics at the University of Hassan I where he carries his research on higher education graduates' employability.

Youssef Lakrari (y.lakrari@uhp.ac.ma) is a PhD candidate at the University of Hassan I (Morocco) where he is a member of the Laboratory of Research in Theoretical and Applied Economics.

Abdeljabbar Abdouni (a.abdouni27@gmail.com) is a Professor of Economics at the University Hassan I (Morocco), Head of Department of Economics and Director of the Laboratory of Research in Theoretical and Applied Economics.

More information about the authors is available at the end of this article (after the bibliography list). 
Keywords: Tuning approach; competences and skills; Mincer equation; Higher education; Human capital; wages; labour market.

\section{Introduction}

Many economists and sociologists in the modern economy have argued that competences of the labour force are becoming more relevant in obtaining higher wages. Recent studies have found evidence of the labour economy trend moving into competence-based roles, and there are an increasing the number of people with higher levels of education and more skilled occupations in the labour force. ${ }^{1}$ In developed economies, the knowledge economy is shifting labour market demands for competences, providing a key engine for economic growth. ${ }^{2}$ Although there is strong agreement on that, there is far less consensus on the kinds of competences most likely needed through the effect of technological change. In that context, developing countries, particularly African countries, must show commitment towards and be prepared for the knowledge economy transition. This is an important challenge facing Africans in higher education institutions and policymakers. Fortunately, the Tuning Africa project ${ }^{3}$ is the first to address those challenges by implementing the competence-based approach in different universities, which shows the commitment of Africans universities to build best competences quality needed in the labour market.

The main goal of this study is to examine the kinds of competences that lead to high, medium or low wages. It is interesting to investigate how different competences performed by higher education graduates are evaluated in the Moroccan labour market. No study on this topic has been carried out yet in the country. The core question that we attempt to address using graduates' self-assessment on competences required in their current work is as follows: "Which competences of graduates are most important to the labour market in explaining income differences?" We also investigate the hypothesis that generic or specific competences of graduates are the key determinants of all levels of wages in more competitive markets compared to

${ }^{1}$ Francis Green, Skills and Skilled Work : An Economic and Social Analysis, $1^{\text {st }}$ ed. (Oxford University Press, 2013): 58.

2 Barbara Sianesi and John V. Reenen, "The Returns to Education: Macroeconomics," Journal of Economic Surveys 17, no. 2 (April 2003): 157-200, https://doi:10.1111/14676419.00192 .

3 The description and more information on Tuning Africa project can be found at the website $<$ http://tuningafrica.org/en/\#>. 
less competitive ones. Moreover, we focus on the economic returns across different fields of study (economics, accounting, engineering, etc.) of higher education graduates. We challenge the standard arguments by using a new dataset from a survey on the employability of higher education graduates in a Moroccan university.

A long debate in the literature emerged over the effect of competences on wages in labour markets. The fundamental well-known human capital theory ${ }^{4},{ }^{5}$ became the backbone of a scientific pattern that attempted to give an explanation for the relationship that exists between level of competences and wages. We were inspired by the work of Green et al., ${ }^{6}$ using a model where competences are essentially divided into either generic or specific. In addition to this model, we attempt to adapt the Mincer equation to the Green model, which provides an estimation of the average payoff returns of two categories of competences through wages.

The first step is the identification of competences that are more relevant to graduates. ${ }^{7}$ To do that, we use data from the Longitudinal Graduates' Employability Survey, which was completed by 1,177 graduates of the cohorts 2011/2012 to 2013/2014. The survey is carried out each year by the University Hassan 1st in partnership with the Moroccan Superior Council of Education. The survey gathers information on many aspects, including the level and kinds of competences and wages of graduates three years after graduation. Our analysis is based on the self-assessment of competences by these graduates. The concept of competences used in the survey is specified through two main elements: generic competences (general knowledge: crossdisciplinary knowledge, critical thinking) composed of motivations, methodological skills and social skills; the second is on specific competences (field-specific: theoretical knowledge, knowledge of methods). The following appropriate model was used: conventional ordinary least square (OLS) regression model containing indicators of wages level and competences, with

4 Jacob Mincer, and Solomon Polachek, "Family Investment in Human Capital: Earnings of Women," Journal of Political Economy 82, no. 2 (1974): 76-110, https://doi. org/10.1086/260293.

${ }^{5}$ Gary S. Becker, Human Capital: A Theoretical and Empirical Analysis, with Special Reference to Education, $2^{\text {ed }}$ ed. (New York: National Bureau of Economic Research, 1964): 45.

${ }^{6}$ Francis Green, "The Value of Skills" (Department of Economics Discussion Paper, no. 9819, University of Kent,,1998): 15, http://hdl.handle.net/10419/105517.

${ }^{7}$ Busato V. Vittorio et al., "Intellectual Ability, Learning Style, Personality, Achievement Motivation and Academic Success of Psychology Students in Higher Education," Personality and Individual Differences 29, no. 6 (2000): 68, https://doi:10.1016/S0191-8869(99)00253-6. 
control variables, such as personal characteristics, occupation characteristics, fields of study, and dummies variables on each institution of the university.

According to our results, we find some evidence in favour of a positive effect of generic competences and methodological skills on wages, with specialised competences having a less important effect. However, education returns (monetary payoff) and work experience seem to correspond with increasing income. We also show that females earn much lower wages than males. These results are very sensitive to the assessment method used in the survey (self-assessment). We consider that self-assessment of graduates' competences (also considered as employees) can lead to biased measures in a certain way, especially for the competences related directly to their work or tasks. On the other side, the employers' assessment can also be biased because they cannot assess graduates' competences that are unrelated to the work (in most cases). Only graduates can provide unbiased measures of these non-work-related competences. This situation suggests that the study should also take into account the employers' assessment of graduates' competences and combine both assessments to achieve a better competences evaluation. ${ }^{8}$

The paper is organised as follows: the next section (2) provides the theoretical approach to the linkage between wages and competences, focusing on the Mincer equation. Section (3) describes data sources and outlines estimation methods. Section (4) presents the results for the estimation model. Finally, section (5) summarises and provides policy implications.

\section{Competences and wages: related literature}

\section{II.1. Theoretical approach: theory of human capital}

The competences and wages in labour markets have been widely debated, as many empirical studies find different and sometimes conflicting results. The theoretical literature itself prescribes different effects that competences have on the wages of higher education graduates. The theoretical difference is related to various studies with different backgrounds; for instance, psychologists, sociologists and the human capital theory view competences in different ways. In particular, we focus our attention on the human capital theory, which treats competences as personal attributes leading to the ability to successfully perform the job requirements.

${ }^{8}$ The start of the survey, the study was generally on the graduates, and unfortunately there wasn't any budget to pursue other targets. 
Becker $^{9}$ and Mincer $^{10}$ found that the degree of competences has a significant effect on wages and earnings. Thus, competences are essentially divided into either general or specific. Becker and Mincer argued that higher levels of education correlate with higher return earnings. The first formulation was made by Mincer: a framework model that clearly associates income (or wages) and years of education and experience. The model takes a standard specification form as follows:

$$
\ln \left(w_{i}\right)=\alpha_{0}+\beta_{1} e d u c_{i}+\beta_{2} \exp _{i}+\beta_{3} \exp _{i}^{2}+\varepsilon_{i},
$$

where $\ln \left(w_{i}\right)$ represents the logarithm of wages including bonuses of the individual $\boldsymbol{i}, e d u c_{i}$ is years of education, $\exp _{i}$ is years of work experience (measured in years), and $\varepsilon_{i}$ is the error term. The development of this research later focused on different types of skills and competences that impact wages. ${ }^{11}$

Several studies included competence variables in the Mincer equation to measure both the effect of education and competences or skills, particularly after the increased enrolment in higher education, which raised doubt about possible negative effects of the overeducation on wages. ${ }^{12},{ }^{13},{ }^{14}$ Higher education graduates are facing critical changes in the labour market; years of education undertaken are no longer enough to find a job matching their degree (and in term of wages). Indeed, general and specific competences are the key element for productivity and professional success for graduates. ${ }^{15}$ The empirical relation between skills and wages can be expressed by Mincerian wage equation as follows:

${ }^{9}$ Becker, Human Capital, 45.

${ }^{10}$ Mincer, and Polachek, "Family Investment in Human Capital: Earnings of Women," 76-110.

${ }^{11}$ Francis Green and Nicholas Tsitsianis, "Can the Changing Nature of Jobs Account for National Trends in Job Satisfaction?," British Journal of Industrial Relations 43, no. 3 (2005): 29.

${ }_{12}$ Richard B. Freeman, The Overeducated American, no 186 (New York: Academic Press, 1976), 120.

${ }^{13}$ Rumberger W. Russell, "The Rising Incidence of Overeducation in the U.S. Labor Market," Economics of Education Review 1, no. 3 (June 1981): 296-297, https:// doi:10.1016/0272-7757(81)90001-7.

${ }^{14}$ David B. Bills, "Credentials, Signals, and Screens: Explaining the Relationship between Schooling and Job Assignment," Review of Educational Research 73, no. 4 (2003): 449, https://www.jstor.org/stable/3515999?seq=1\#page_scan_tab_contents.

15 Rolf D. Velden, and Ineke Bijlsma, "College Wage Premiums and Skills : A CrossCountry Analysis," Oxford Review of Economic Policy 32, no. 4 (2016): 507, https:// doi:10.1093/oxrep/grw027. 
$\ln \left(w_{i}\right)=\alpha_{0}+\beta_{1} e d u c_{i}+\beta_{2} \exp _{i}+\beta_{3} \exp _{i}^{2}+\beta_{4} \operatorname{com}_{i 1} \ldots \ldots+\beta_{n} \operatorname{com}_{i n}+\varepsilon_{i}$,

The specification includes a measure of $n$ competences $\left(\operatorname{com}_{i n}\right)$ to identify which competences are most valuable in monetary payoff terms. We contribute to this literature, which has mostly focused on developed countries ${ }^{16},{ }^{17},{ }^{18},{ }^{19}$ by estimating the impact of competences on wages of higher education graduates - an issue that, to the best of our knowledge, has not yet been investigated thoroughly in the case of Morocco.

\section{II.2. Categories of competences in the literature}

Our analysis is related to various other studies on how human capital skills and competences are rewarded in the labour market. ${ }^{20}{ }^{21}$ In particular, Becker ${ }^{22}$ classified competences into specific to generic competences required from the firm (well-known as "Becker's classification"). Green ${ }^{23}$ examined the impact of different competences on wages using a principal component analysis, identifying groups of competences such as verbal, manual, problem solving and checking, numerical, and professional communication. Escrig and $\mathrm{Bou}^{24}$ highlighted that competences can be

${ }^{16}$ Authors used the dataset from Program of the International Assessment of Adult Competencies (PIAAC) developed by OECD to assess the effect of skills on wages. OECD, OECD Skills Outlook 2013: First Results from the Survey of Adult Skills (OECD Publishing, 2013), 141-77, http://dx.doi.org/10.1787/9789264204256-en.

${ }^{17}$ Green, "The Value of Skills," 15.

${ }^{18}$ Mark Levels, Rolf D. Velden, and Jim Allen, "Educational Mismatches and Skills: New Empirical Tests of Old Hypotheses," Oxford Economic Papers 66, no. 4 (October 2014): 976, https://doi:10.1093/oep/gpu024.

19 Eric A. Hanushek et al., "Returns to Skills around the World: Evidence from PIAAC," European Economic Review 73 (January 2015): 120-124, https://doi:10.1016/j. euroecorev.2014.10.006.

${ }^{20}$ Richard Arum and Yossi Shavit, "Secondary Vocational Education and the Transition from School to Work," Sociology of Education 68, no. 3 (July 1995): 187, https:// doi:10.2307/2112684.

${ }^{21}$ Dominique S. Rychen and Laura H. Salganik, Key Competencies for a Successful Life and a Well-Functioning Society (Hogrefe \& Huber, 2003): 180, https://books.google.co.ma/ books?id=GK63AAAAIAAJ.

${ }^{22}$ Becker, Human Capital, 65.

${ }^{23}$ Francis Green, Skills and Skilled Work, 25.

${ }^{24}$ Escrig-Tena A. B, and Bou-Llusar J. C., "A Model for Evaluating Organizational Competencies: An Application in the Context of a Quality Management Initiative," Decision Sciences 36, no. 2 (May 2005): 248, https://doi:10.1111/j.1540-5414.2005.00072.x. 
empirically classified into four main clusters; the researchers assembled competences into categories, which simplify the estimation of the impact of competences. The categories were managerial, input-based, transformationbased, and output-based, and we find that cognitive competences and general knowledge tend to accelerate the process of acquisition of target competences.

Kellermann ${ }^{25}$ showed that competences are listed in five dimensions that are required for productivity at work: (1) general-academic, (2) scientific-operative, (3) personal-professional, (4) social-reflexive, and (5) physiological-handicraft. Aracil and Velden ${ }^{26}$ distinguished the competences into six categories using principal components analysis (PCA) for 32 listed competences. The six factors were labelled by organisational, specialised, methodological, generic, participative, and socio-emotional competences. All things considered, it seems reasonable to assume that in theory, there is no overall consensus on the classification of competences. Therefore, available data are used to determine the categories of competences in each study.

Inspired by the literature on the classification of competences above and the available data in our sample, we categorise the 19 competences (based on the literature and the context of Moroccan labour markets) cited in our survey into 3 main categories. It is a common practice to remove the problem of multicollinearity among competences. Table (1) gives an overview of the competences aggregated in categories.

Table 1

Classification of competences

\begin{tabular}{|l|l|}
\hline \multicolumn{1}{|c|}{ Categories } & \multicolumn{1}{c|}{ List of Competences } \\
\hline Generic & Knowledge Cross fields and discipline \\
\cline { 2 - 3 } & Critical and reflective thinking \\
\cline { 2 - 3 } & Communication skills \\
\cline { 2 - 2 } & Coordinating and planning \\
\cline { 2 - 2 } & Written communications skills \\
\hline
\end{tabular}

${ }^{25}$ Kellermann Paul, "Acquired Competences and Job Requirements," in Careers of University Graduates, ed. Springer, Dordrech (U. Teichler, vol 17, 2007), 120-23.

${ }^{26}$ Adela G. Aracil and Rolf D. Velden, "Competencies for Young European Higher Education Graduates: Labor Market Mismatches and Their Payoffs," Higher Education 55, no. 2 (2008): 229, https: doi:10.1007/s10734-006-9050-4. 


\begin{tabular}{|c|c|}
\hline Categories & List of Competences \\
\hline \multirow[t]{7}{*}{ Methodological skills } & Adaptability \\
\hline & Performs well under pressure \\
\hline & Time management \\
\hline & Computer skills \\
\hline & Problem-solving ability \\
\hline & Documenting ideas or reporting to an audience \\
\hline & Foreign language proficiency \\
\hline \multirow[t]{4}{*}{ Social skills } & Leadership \\
\hline & Ability to negotiate \\
\hline & Working in a team \\
\hline & Ability to mobilise the capacities of others \\
\hline \multirow[t]{3}{*}{ Specialised } & Own field or discipline (theoretical knowledge) \\
\hline & Own field or discipline (knowledge of methods) \\
\hline & Learning abilities- Methods \\
\hline
\end{tabular}

Source: Authors.

\section{Data and methodology}

In this section, we briefly describe the data we used and the broad steps of our estimation method. Readers interested in the complete details of our estimations are referred to the extensive appendices at the end of the paper. Our data were obtained from the Longitudinal Graduates' Employability Survey ${ }^{27}$ which was carried out each year by the University Hassan I in partnership with the Moroccan Superior Council of Education. Each subsequent year since 2012, the cohort graduates from 2010/2011,2012/2013, and 2014/2015 were surveyed 3 years after their graduation. We excluded graduates without working experience from this dataset since we are focusing only on competences and wages. Table (2) provides summary statistics for the competences listed in the previous table (1) of 1,177 graduates with paid

${ }^{27}$ Annex A provides information on the size of the sample in each survey. 
work experience. Graduates were asked to assess their competences on a ranking scale from 1 (very low) to 4 (very high).

\section{Table 2}

Descriptive statistics

\begin{tabular}{|c|c|c|c|}
\hline Categories & List of Competences & Mean & $\begin{array}{l}\text { Standard } \\
\text { deviation }\end{array}$ \\
\hline \multirow[t]{5}{*}{ Generic } & Knowledge cross fields and discipline & 3.27 & 0.69 \\
\hline & Critical and reflective thinking & 3.29 & 0.77 \\
\hline & Communication skills & 3.50 & 0.72 \\
\hline & Coordinating and planning & 3.49 & 0.71 \\
\hline & Written communications skills & 3.45 & 0.75 \\
\hline \multirow{7}{*}{$\begin{array}{l}\text { Methodological } \\
\text { skills }\end{array}$} & Adaptability & 3.13 & 0.85 \\
\hline & Performs well under pressure & 3.44 & 0.72 \\
\hline & Time management & 3.52 & 0.65 \\
\hline & Computer skills & 3.68 & 0.62 \\
\hline & Problem-solving ability & 3.46 & 0.71 \\
\hline & $\begin{array}{l}\text { Documenting ideas or reporting to an } \\
\text { audience }\end{array}$ & 3.38 & 0.78 \\
\hline & Foreign language proficiency & 3.35 & 0.72 \\
\hline \multirow[t]{4}{*}{ Social skills } & Leadership & 3.28 & 0.76 \\
\hline & Ability to negotiate & 3.28 & 0.80 \\
\hline & Working in a team & 3.70 & 0.59 \\
\hline & $\begin{array}{l}\text { Ability to mobilise the capacities of } \\
\text { others }\end{array}$ & 3.29 & 0.81 \\
\hline \multirow[t]{3}{*}{ Specialised } & $\begin{array}{l}\text { Own field or discipline (theoretical } \\
\text { knowledge) }\end{array}$ & 3.55 & 0.62 \\
\hline & $\begin{array}{l}\text { Own field or discipline (knowledge of } \\
\text { methods) }\end{array}$ & 3.60 & 0.61 \\
\hline & Learning abilities- Methods & 3.67 & 0.60 \\
\hline
\end{tabular}

Source: Authors' estimations.

Tuning Journal for Higher Education 
The mean test of competence categories shows that three specialised competences scored more than 3.5, a high value, which represent those competences for higher education graduates. However, generic competences appear with one competence scoring more than the previous average score. Methodological competences have just two competences greater than 3.5. The only elements among social competences scored more than a mean of 3.5 was working in a team. The resulting values are displayed in figure (1).

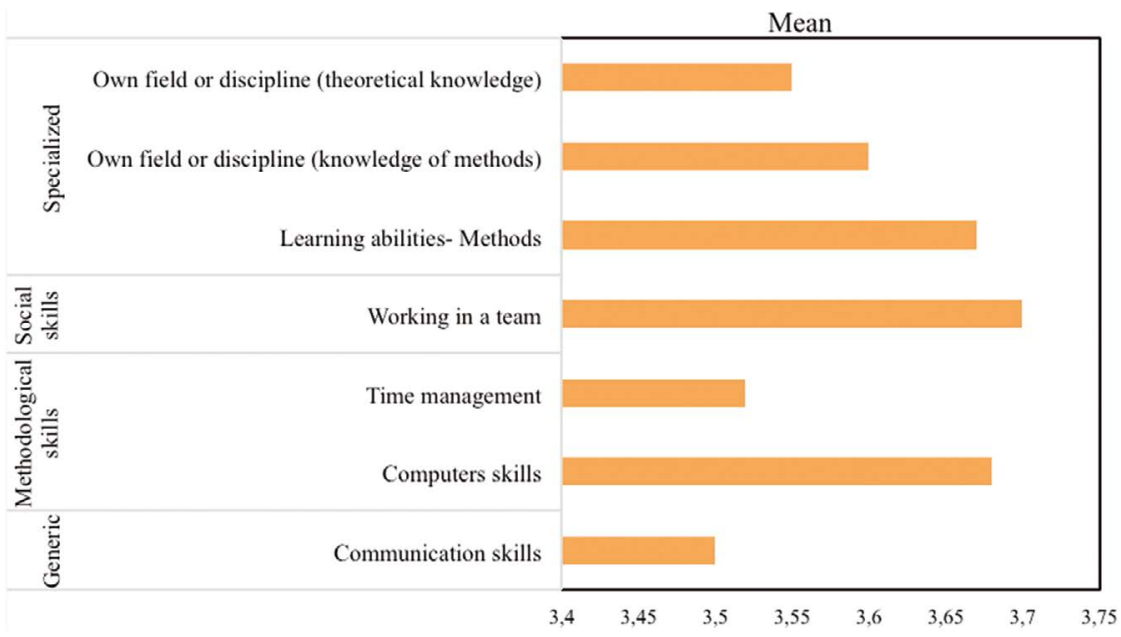

Source: Authors' estimations.

\section{Figure 1}

\section{Competences classification by mean score}

Since many conventional studies on competences using regression models revealed the existence of the multicollinearity problem ${ }^{28}$ among competences ${ }^{29} ;{ }^{30} ;{ }^{31}$, we applied a factor analysis to the 19 competences, and

${ }^{28}$ Strong multicollinearity may generate misleading inferences, especially in the interpretation of coefficients of the model.

${ }^{29}$ Green, "The Value of Skills," 25.

${ }^{30}$ Levels, Velden, and Allen, "Educational Mismatches and Skills," 973.

${ }^{31}$ Andrés F. García-suaza, Juan C. Guataquí, and José Alberto, "Beyond the Mincer Equation: The Internal Rate of Return to Higher Education in Colombia," Education Economics 22, no. 3 (2014): 337, https://doi:10.1080/09645292.2011.595579. 
we used the orthogonal factor scores which are uncorrelated (for a detailed description, see Annexes table B and C). As noted before, economists have no consensus theory for evaluating monetary payoff effects of competences, leaving the question open for empirical study. To assess the empirical effects, we need control variables, such as personal characteristics, occupation characteristics, fields of study, and dummy variables on each institution of the university. The choice of those control variables in our regression is based on human capital theory and most commonly used in empirical regressions. The employed control variables are described below with their meanings and statistics (Table 3).

Table 3

Control variables and summary statistics

\begin{tabular}{|c|c|c|c|c|c|}
\hline Variables & Description & Mean & St. Dev & Min & Max \\
\hline Wages & Logarithm of salary & 5891.84 & 85.27 & 400 & 28800 \\
\hline \multicolumn{6}{|c|}{ Personal characteristics } \\
\hline Female & 1: if female. and 0 otherwise & $44.01 \%$ & - & 0 & 1 \\
\hline Married & 1 : if married. and 0 otherwise & $23.36 \%$ & - & 0 & 1 \\
\hline Age & In years & 29.91 & 0.19 & 19 & 58 \\
\hline Education & $\begin{array}{l}\text { Number of years in higher } \\
\text { education }\end{array}$ & 3.86 & 1.11 & 2 & 9 \\
\hline \multicolumn{6}{|c|}{ Occupation characteristics } \\
\hline $\begin{array}{l}\text { Experience } \\
\text { work }\end{array}$ & Work experience in years & 2.14 & 1.12 & 0.08 & 4.33 \\
\hline Private sector & $\begin{array}{l}\text { 1: employed in the private } \\
\text { sector }\end{array}$ & $65.25 \%$ & - & 0 & 1 \\
\hline Public sector & 1: employed public sector & $34.75 \%$ & - & 0 & 1 \\
\hline City & $\begin{array}{l}\text { 1: large city. and } 0 \\
\text { otherwise }\end{array}$ & $78.75 \%$ & - & 0 & 1 \\
\hline \multicolumn{6}{|l|}{ Major field } \\
\hline $\begin{array}{l}\text { Social science. } \\
\text { business and } \\
\text { law }\end{array}$ & $\begin{array}{l}\text { 1: graduate in the field. and } \\
0 \text { otherwise }\end{array}$ & $58.62 \%$ & - & 0 & 1 \\
\hline $\begin{array}{l}\text { Science \& } \\
\text { engineering }\end{array}$ & $\begin{array}{l}\text { 1: graduate in field. and } 0 \\
\text { otherwise }\end{array}$ & $41.37 \%$ & - & 0 & 1 \\
\hline
\end{tabular}




\begin{tabular}{|l|l|c|c|c|c|}
\hline \multicolumn{1}{|c|}{ Variables } & \multicolumn{1}{|c|}{ Description } & Mean & St. Dev & Min & Max \\
\hline \multicolumn{2}{|c|}{ Institutions characteristics } \\
\hline $\begin{array}{l}\text { Open } \\
\text { institutions }\end{array}$ & $\begin{array}{l}1: \text { open access. and } 0 \\
\text { otherwise }\end{array}$ & $48.08 \%$ & - & 0 & 1 \\
\hline $\begin{array}{l}\text { Limited entry } \\
\text { institution }\end{array}$ & $\begin{array}{l}\text { 1: limited access. and 0 } \\
\text { otherwise }\end{array}$ & $51.91 \%$ & - & 0 & 1 \\
\hline Observations & 1,177 with work experience & - & - & - & - \\
\hline
\end{tabular}

Source: Authors' estimations.

We add the initial $(\log )$ level of the wages to be in line with the linearity assumption of Mincer's equation. The list of dependent variables containing indicators on control variables for personal characteristics, job characteristics, major field of study, occupation in own domain, and for the distinction between university institutions (limited or open access).

\section{Model and estimation results}

\section{IV.1. Model}

In this section, we develop a model using ordinary least squares (OLS) regression to analyse the effects of competences and other variables on wages of higher education graduates. To do that, we adopt an extended version of the Mincer equation developed in the literature section. The dependent variables listed in Table (3) are used in the following equation estimation:

$$
\begin{gathered}
\ln \left(W_{i}\right)=\alpha_{0}+\beta_{1} \text { Educ }_{i}+\beta_{2} \operatorname{Exp}_{i}+\beta_{n} \sum_{F=1}^{9} \text { Com }_{\text {in }}+ \\
+\beta_{3} \text { Pel }_{i}+\beta_{4} \text { Job }_{i}+\beta_{5} \text { Field }_{i}+\beta_{6} \text { Insti }_{i}+\varepsilon_{i},
\end{gathered}
$$

We use the 9 factors scores generated by the PCA results for competence variables $\operatorname{Com}_{i n}$. Educ $c_{i}$ and $\operatorname{Exp}_{i}$ denote education and work experience in years, respectively. The rest of the variables are binary dummies controlling for personnel and occupation characteristics, and institutions attended. As outlined in the introduction, we formulate some questions on competences and wages for higher education graduates, and 
in the line with human capital theory, we would expect the responses of the coefficients to be those shown in table (4).

Table 4

Expected and estimated responses of model

\begin{tabular}{|l|c|c|}
\hline \multicolumn{1}{|c|}{ Variables } & Expected responses & Estimated responses \\
\hline Competences & $(+)$ & $(+)$ \\
\hline Education & $(+)$ & $(+)$ \\
\hline Field (Social vs science) & $?$ & $(+)$ \\
\hline Experience & $(+)$ & $(+)$ \\
\hline Female & $(-)$ & $(-)$ \\
\hline Private vs Public & $(-)$ & $(-)$ \\
\hline Open vs limited institutions & $(-)$ & $(-)$ \\
\hline Married & $?$ & No effect \\
\hline Age & $(+)$ & No effect \\
\hline City (large vs small) & $(+)$ & No effect \\
\hline
\end{tabular}

Additionally, we expect the wages to be driven by competences; thus, we assume the following hypotheses. (HI) The wages are partly explained by the higher proficiency in specified competences of higher-educated graduates compared to generic competences. (H2) Sector differences in wages are partly explained by differences in labour market institutions: wages are higher in the public sector than in the private sector. (H3) Wages are partly explained by personal characteristics and the types of institutions (graduates of limited institutions tend to have higher wages than those from open institutions).

\section{IV.2. Empirical findings}

Table (5) presents the estimation results of the Mincer wage equation. For each model, we provide two sets of results: one for the model (I) with all variables, and the other (II) is where we keep the variables with significant variables. The estimation results are consistent with some previous studies exploring the relationships among wages, education and experience. 


\section{Table 5}

Estimation of wages equation

\begin{tabular}{|c|c|c|c|c|c|}
\hline Variables & Model I & Model II & & Model I & Model II \\
\hline F1 & $\begin{array}{l}0.02896 * * * \\
(0.0001)\end{array}$ & $\begin{array}{l}0.03073 * * \\
(0.0001)\end{array}$ & ddl & 1158 & 1158 \\
\hline $\mathrm{F} 2$ & $\begin{array}{l}0.02811 * \\
(0.0183)\end{array}$ & $\begin{array}{l}0.030 * * \\
(0.0115)\end{array}$ & $\mathrm{R}^{2}$ adjusted & 0.25 & 0.2575 \\
\hline F3 & $\begin{array}{l}0.01218 \\
(0.3206)\end{array}$ & & MCE & 0.205 & 0.2050 \\
\hline $\mathrm{F} 4$ & $\begin{array}{l}0.00038 \\
(0.9764)\end{array}$ & & RMCE & 0.4542 & 0.4528 \\
\hline F5 & $\begin{array}{l}0.0033 \\
(0.8048)\end{array}$ & & DW & 1.8462 & 1.8423 \\
\hline F6 & $\begin{array}{l}-0.01675 \\
(0.2441)\end{array}$ & & & & \\
\hline F7 & $\begin{array}{l}0.0136 * \\
(0.0840)\end{array}$ & $\begin{array}{l}0.01570 * \\
(0.0830)\end{array}$ & & & \\
\hline F8 & $\begin{array}{l}-0.01441 \\
(0.3569)\end{array}$ & & & & \\
\hline F9 & $\begin{array}{l}0.02946 * \\
(0.0634)\end{array}$ & $\begin{array}{l}0.030 * * * \\
(0.054)\end{array}$ & & & \\
\hline Education & $\begin{array}{l}0.12030 * * * \\
(0.0001)\end{array}$ & $\begin{array}{l}0.1491 * * * \\
(0.0001)\end{array}$ & & & \\
\hline Age & $\begin{array}{l}0.000843 \\
(0.7054)\end{array}$ & & & & \\
\hline Experience work & $\begin{array}{l}0.07644 * * * \\
(0.0001)\end{array}$ & $\begin{array}{l}0.0842 * * * \\
(0.0001)\end{array}$ & & & \\
\hline Female & $\begin{array}{l}-0.10724 * * * \\
(0.0001)\end{array}$ & $\begin{array}{l}-0.0935 * * * \\
(0.0001)\end{array}$ & & & \\
\hline Married & $\begin{array}{l}0.01950 \\
(0.5956)\end{array}$ & & & & \\
\hline Private vs Public & $\begin{array}{l}-0.15174 * * * \\
(0.0001)\end{array}$ & $\begin{array}{l}-0.1087 * * * \\
(0.0001)\end{array}$ & & & \\
\hline
\end{tabular}




\begin{tabular}{|l|l|l|l|l|l|}
\hline \multicolumn{1}{|c|}{ Variables } & \multicolumn{1}{|c|}{ Model I } & \multicolumn{1}{|c|}{ Model II } & & Model I & Model II \\
\hline City & $\begin{array}{l}0.04481 \\
(0.18165)\end{array}$ & & & & \\
\hline $\begin{array}{l}\text { Field (Social vs } \\
\text { science) }\end{array}$ & $0.12453 * * *$ & $0.12453 * * *$ & & & \\
\hline $\begin{array}{l}\text { Institutions } \\
\text { (open vs limited) }\end{array}$ & $\begin{array}{l}-0.17023 * * * \\
(0.0002)\end{array}$ & $-0.17023 * * *$ & & & \\
\hline Constant & $\begin{array}{l}8.0157 * * * \\
(0.0001)\end{array}$ & $\begin{array}{l}7.9097 * * * \\
(0.0001)\end{array}$ & & & \\
\hline Observations & 1,177 & 1,177 & & & \\
\hline R-squared & 0.2675 & 0.2675 & & & \\
\hline
\end{tabular}

Notes: The dependent variable is the log of month salary including bonuses. The first Model I contain all listed explanatory variables. The second Model II contain only significant variables from the first model I. The $P$-values are in parentheses. ${ }^{*} p<0.1$. ${ }^{* *} p<0.05$. ${ }^{* * *} p<0.01$.

Source: Authors' estimations.

We find a weak significant effect of some competences on wages among higher education graduates; however, the model shows that 12 out of 19 competences have a positive impact. Those competences are as follows:

- (Specialised)

Learning abilities

$-($ Generic $)$

Critical and reflective thinking

Written communications skills

Coordinating and planning

- (Methodological skills)

Computer skills

Adaptability

Documenting ideas or reporting to an audience

Foreign language proficiency

Performs well under pressure

- (Social skills)

Ability to negotiate

Leadership

Ability to mobilise the capacities of others 


\section{Table 6}

Coefficients of competencies in the model

\begin{tabular}{|l|l|c|c|}
\hline \multicolumn{1}{|c|}{ Categories } & \multicolumn{1}{|c|}{ Competences } & Model II & P-values \\
\hline Specialised & Learning abilities- Methods & $0.03073 * *$ & $(0.0001)$ \\
\hline \multirow{4}{*}{ Generic } & Critical and reflective thinking & $0.03073 * *$ & $(0.0001)$ \\
\cline { 2 - 4 } & Coordinating and planning & $0.03073 * *$ & $(0.0001)$ \\
\cline { 2 - 4 } & Written communications skills & $0.030 * *$ & $(0.0115)$ \\
\hline \multirow{5}{*}{$\begin{array}{l}\text { skills } \\
\end{array}$} & Adaptability & $0.03073 * *$ & $(0.0001)$ \\
\cline { 2 - 4 } & Documenting ideas & $0.030 * *$ & $(0.0115)$ \\
\cline { 2 - 4 } & Foreign language proficiency & $0.030 * *$ & $(0.0115)$ \\
\cline { 2 - 4 } & Computer skills & $0.01570 *$ & $(0.0830)$ \\
\cline { 2 - 4 } & Performs well under pressure & $0.030 * * *$ & $(0.054)$ \\
\hline \multirow{3}{*}{ Social skills } & Ability to negotiate & $0.01570 *$ & $(0.0830)$ \\
\cline { 2 - 4 } & Leadership & $0.030 * * *$ & $(0.054)$ \\
\cline { 2 - 4 } & Ability to mobilise capacities of others & $0.030 * * *$ & $(0.054)$ \\
\hline Observations & & & 1,177 \\
\hline R-squared & \multicolumn{3}{|c|}{0.2675} \\
\hline
\end{tabular}

Notes: The dependent variable is the log of month salary including bonuses. The second Model II contain only significant variables from the first model I. $P$-values are in parentheses. $* \mathrm{p}<0.1$. ** $\mathrm{p}<0.05$. *** $\mathrm{p}<0.01$.

Source: Authors' estimations.

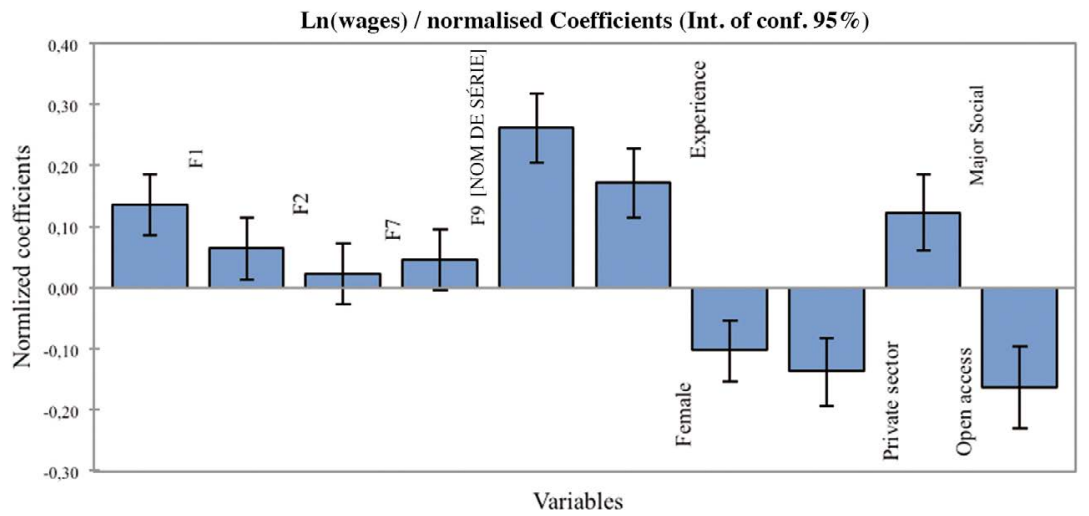

Source: Authors' estimations.

Figure 2

Estimated coefficients of the model 
According to the results of table (6), we could accept hypothesis (HI); thus, the generic competences are more important in explaining the wages variance in our sample, leading us to reject $(H 1)$. As expected, the $(H 2)$ is valid, which means that graduates working in the private sector are rewarded less compared to those in the public sector. We conclude that working in the private sector can adversely affect wages. The estimations show a good validation of $(\mathrm{H} 3)$, even though the social field was expected to have a negative effect. Based on these outcomes, we can highlight that our results show a similar negative effect for female graduates as shown in other studies $.{ }^{32},{ }^{33},{ }^{34}$ Figure (2) allows us to directly compare the relative influence and significance of the explanatory variables on the wages.

\section{Concluding remarks}

In this paper, we analyse the empirical relationship between competences and wages of higher education graduates. Using survey data from the University Hassan I, we find some evidence supporting a positive effect of generic competences and methodological skills, with the less important effect of specialised competences. This result can lead to some questions regarding the assessment method. By contrast, personal and job characteristics lead to a closer expected effect.

Nevertheless, it suffers from the problem measurement of competences, because the empirical model shows that the variation in low wages can be explained by the competences, which are scored on a scale from low to high. This problem occurs when graduates give an arbitrary choice of three to four modalities. In this context, the measurement scale developed in many studies report a low coefficient of determination $\left(\mathrm{R}^{2}=0.27\right)$. In this sense, the recommendation for further empirical studies, especially at the moment of the elaboration of the survey, is to use a simple scale percentage measurement instrument instead of modalities to assess competences among graduates. This method will enable us to have a more accurate measurement instrument, but these results were very sensitive to the

${ }^{32}$ Garcia, Guataquí, and Alberto, "Beyond the Mincer Equation,” 229.

${ }^{33}$ Paul Koshy, Richard Seymour, and Mike Dockery, "Are There Institutional Differences in the Earnings of Australian Higher Education Graduates ?," Economic Analysis and Policy 51 (2016): 08, https://doi:10.1016/j.eap.2016.05.004.

${ }^{34}$ Hanol Lee, Jong-wha Lee, and Eunbi Song, "Effects of Educational Mistmatch on Wages in the Korean Labor Market," East Asian Economic Association and John Wiley \& Sons Australia, 30, no. 4, (2016): 381-390. 
assessment method used to measure competences in the survey (selfassessment).

We suggest that the reason behind the low values of competence coefficients is that the labour market of the study has not yet been polled using these levels of competence; in contrast, the market is still dominated by education and work experience factors. We also showed that females earn far less than males in term of wages. Our empirical findings also suggest that the labour market rewards less specialised competences than other competencies; this finding provides a valuable insight and indicates that we should continue to study such results.

Many African academics and policymakers remain ambiguous about graduate competences and skills that match well with labour market requirements. We aimed to develop assessments and indicators of competences that would have an influence in the labour market and provide baseline information needs in terms of knowledge, skills and competences for policymakers. Our Mincerian model results can help practitioners and policy-makers to make better decisions. For instance, the private sector appears to attribute fewer rewards to graduates' competences than the public sector is doing. Additionally, the study reports the existence of a gap in wages between female and male graduates. Hence, policymakers need to make more efforts to ensure equal wages for both genders.

The dynamic of the labour market and the overeducation effect have to change the traditional situation into a new one, in which methodological and social competences are deemed more necessary than cognitive skills (theoretical knowledge). This finding prompted a re-thinking of key competences and skills required of higher education graduates. ${ }^{35}$

Finally, our study is far from being free of limitations. We have attempted to reduce the limitations in our empirical analysis; however, additional questions still remain unsolved and should therefore be addressed in future research. For example, our study relies on graduates' assessment of competences. It would be interesting to replicate this research by exploring the competences required by employers and analysing the causal effects of both acquired and required competences.

${ }^{35}$ This results are in line with the findings reported in a recent study of the Hamilton project: Diane Whitmore Schanzenbach et al., 2017. 'Seven Facts on Noncognitive Skills from Education to the Labour Market'. It is in fact a new evolution: while cognitive skills (like English or mathematics) have long been used to match job requirements, the non-cognitive skills (communication, teamwork, leadership, self-motivated, etc.) are becoming increasingly important and more integral to the labour market.

‘ttp://www.hamiltonproject.org/assets/files/seven_facts_noncognitive_skills_ education_labor_market.pdf> 


\section{Bibliography}

Arum, Richard, and Yossi Shavit. "Secondary Vocational Education and the Transition from School to Work." Sociology of Education 68, no. 3 (July 1995): 187-04. https://doi:10.2307/2112684.

Becker, Gary S. Human Capital: A Theoretical and Empirical Analysis, with Special Reference to Education. $2^{\text {ed }}$ ed. New York: National Bureau of Economic Research, 1964.

Busato, Vittorio V, Frans J Prins, Jan J Elshout, and Christiaan Hamaker. "Intellectual Ability, Learning Style, Personality, Achievement Motivation and Academic Success of Psychology Students in Higher Education." Personality and Individual Differences 29, no. 6 (2000): 1057-68. https://doi:10.1016/S01918869(99)00253-6.

Bills, B. David. "Credentials, Signals, and Screens: Explaining the Relationship between Schooling and Job Assignment." Review of Educational Research 73, no. 4 (2003): 441-69. https://www.jstor.org/stable/3515999?seq=1\#page_scan_ tab_contents.

Escrig-Tena, Ana Belen, and Juan Carlos Bou-Llusar. “A Model for Evaluating Organizational Competencies: An Application in the Context of a Quality Management Initiative." Decision Sciences 36, no. 2 (May 2005): 221-57. https://doi:10.1111/j.1540-5414.2005.00072.x.

Freeman, B. Richard. The Overeducated American. New York, Academic Press, 1976. https://www.jstor.org/stable/30023104?seq=1\#page_scan_tab_contents.

García-Aracil, Adela, and Rolf Van Velden. "Competencies for Young European Higher Education Graduates: Labor Market Mismatches and Their Payoffs." Higher Education 55, no. 2 (2008): 219-39. https://doi:10.1007/s10734-0069050-4.

García-suaza, Andrés Felipe, Juan Carlos Guataquí, and José Alberto. "Beyond the Mincer Equation: The Internal Rate of Return to Higher Education in Colombia." Education Economics 22, no. 3 (2014): 328-44. https://doi: 10.1080/09645292.2 011.595579 .

Green, Francis. Skills and Skilled Work: An Economic and Social Analysis. $1^{\text {st }}$ ed. Oxford University Press, 2013.

- "The Value of Skills" (Department of Economics Discussion Paper, no. 9819, University of Kent, 1998): 0-35. http://hdl.handle.net/10419/105517.

Green, Francis, and Nicholas Tsitsianis. "Can the Changing Nature of Jobs Account for National Trends in Job Satisfaction?” British Journal of Industrial Relations 43, no. 3 (2005): 401-29.

Hanushek, Eric A., Guido Schwerdt, Simon Wiederhold, and Ludger Woessmann. "Returns to Skills around the World: Evidence from PIAAC." European Economic Review 73 (January 2015): 103-30. https://doi:10.1016/j. euroecorev.2014.10.006.

Koshy, Paul, Richard Seymour, and Mike Dockery. "Are There Institutional Differences in the Earnings of Australian Higher Education Graduates?" 
Economic Analysis and Policy 51 (2016): 1-11. https://doi:10.1016/j. eap.2016.05.004.

Lee, Hanol, Jong-wha Lee, and Eunbi Song. "Effects of Educational Mistmatch on Wages in the Korean Labor Market." East Asian Economic Association and John Wiley \& Sons Australia 30, no. 4 (2016): 375-400.

Levels, M., R. van der Velden, and J. Allen. "Educational Mismatches and Skills: New Empirical Tests of Old Hypotheses." Oxford Economic Papers 66, no. 4 (October 2014): 959-82. https://doi:10.1093/oep/gpu024.

Mincer, Jacob, and Solomon Polachek. "Family Investment in Human Capital: Earnings of Women." Journal of Political Economy 82, no. 2 (1974): 76-110. https://doi.org/10.1086/260293.

Paul, Kellermann. "Acquired Competences and Job Requirements." In Careers of University Graduates, edited by Springer, Dordrech, 115-130. U. Teichler, 2007. https://doi.org/10.1007/978-1-4020-5926-1_7.

OECD. OECD Skills Outlook 2013: First Results from the Survey of Adult Skills. OECD Publishing, 2013. http://dx.doi.org/10.1787/9789264204256-en

Russell, W. Rumberger. "The Rising Incidence of Overeducation in the U.S. Labor Market." Economics of Education Review 1, no. 3 (June 1981): 293-314. https:// doi:10.1016/0272-7757(81)90001-7.

Rychen, Dominique Simone Salganik, Laura Hersh. Key Competencies for a Successful Life and a Well-Functioning Society. Hogrefe \& Huber, 2003. https:// books.google.co.ma/books?id=GK63AAAAIAAJ.

Sianesi, Barbara, and John Van Reenen. "The Returns to Education: Macroeconomics." Journal of Economic Surveys 17, no. 2 (April 2003): 157-200. https:// doi:10.1111/1467-6419.00192.

Velden, Rolf Van Der, and Ineke Bijlsma. "College Wage Premiums and Skills: A Cross-Country Analysis." Oxford Review of Economic Policy 32, no. 4 (2016): 497-513. https://doi:10.1093/oxrep/grw027.

\section{About the authors}

ABDELLAH ABAIDA (a.abaida@uhp.ac.ma) is a PhD candidate in applied economics at the University of Hassan I. He is a member team researcher on higher education graduates' employability of the University Hassan I. He has conducted several research projects on auto-assessment of institutions that are related to the university. Mr. Abaida holds a Masters in Economic expertise from Hassan I (Morocco). He is currently teaching Microeconomics and statistics for undergraduate students at the University Ibn Zohr (Morocco). His doctoral research focuses on Macroeconomics policies, labour market, economic growth, and fiscal policy in developing countries.

YOUSSEF LAKRARI (y.lakrari@uhp.ac.ma) is a PhD candidate at the University of Hassan I (Morocco). He is a member of Laboratory of Research in Theoretical and Applied Economics at the same university. He is also a member of the 
research team on higher education graduates' employability of the University Hassan I. His doctoral research interest and experience focuses on the quality of employability of higher education graduates, Moroccan labour's market and higher education. He holds a Master degree in Economic expertise (University of Hassan I, Morocco).

ABDELJABBAR ABDOUNI (a.abdouni27@gmail.com) is a Professor of economics at the University Hassan I (Morocco), Head of Department of Economics and Director of the Laboratory of Research in Theoretical and Applied Economics. He has collaborated in Tuning Africa project I, and he is currently a member of Tuning Africa project II. Professor Abdouni holds a PhD in Economics from University Aix-Marseille, France. His research examines higher education graduates' employability, human capital, innovation and economic growth, and the transfer of technologies from advanced economies to developing countries. He has conducted many surveys and research on higher education graduates. $\mathrm{He}$ is responsible for coordinating different university studies and projects with the Moroccan Superior Council of Higher Education.

\section{Annexes}

\section{A) Choice of the theoretical survey sample}

To ensure a better representation of the sample, we determined the size by the following formula:

$$
n=\frac{Z^{2} \quad P(1-P)}{\alpha^{2}}
$$

where $\mathrm{Z}(=1.96)$ represents the value of Gauss law with a confident level of $95 \%, \alpha$ is the sampling error $(5 \%)$ and $\mathrm{P}$ represents the probability of achievement of the measured variable "unemployment rate". After five surveys conducted each year since 2012, we choose graduates with work experience among all five surveys to have in total 1,177 graduates in our study. 


\begin{tabular}{|c|c|c|c|c|c|c|c|c|c|c|c|c|}
\hline 운 & 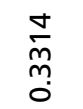 & $\begin{array}{l}\infty \\
0 \\
\emptyset \\
0 \\
0\end{array}$ & 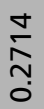 & \begin{tabular}{l}
$\stackrel{9}{T}$ \\
\multirow{2}{0}{} \\
0
\end{tabular} & 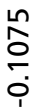 & 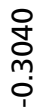 & $\frac{\nwarrow}{\frac{\sigma}{\sigma}}$ & $\frac{\bar{\infty}}{\stackrel{m}{m}}$ & $\begin{array}{l}\text { ஸீ } \\
\text { ก̃ } \\
0\end{array}$ & 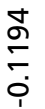 & 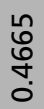 & $\begin{array}{l}0 \\
\stackrel{+}{7} \\
\\
0\end{array}$ \\
\hline 䎹 & $\frac{\stackrel{\circ}{\mathscr{n}}}{\stackrel{0}{0}}$ & $\begin{array}{l}\stackrel{n}{\infty} \\
\stackrel{\infty}{m} \\
o ̣\end{array}$ & 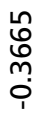 & $\begin{array}{l}0 \\
0 \\
\\
0 \\
0\end{array}$ & $\begin{array}{l}\underset{N}{N} \\
\text { ָे }\end{array}$ & $\frac{⿱ 亠}{m}$ & $\begin{array}{l}\text { 우 } \\
\qquad \\
\circ \\
0\end{array}$ & $\begin{array}{l}\text { No } \\
\text { mọ } \\
0 \\
0\end{array}$ & $\frac{\stackrel{\infty}{\infty}}{\stackrel{\infty}{0}}$ & $\begin{array}{l}\text { 요 } \\
\text { О } \\
\text { ㅇ }\end{array}$ & $\frac{\sim}{\stackrel{N}{\sim}}$ & $\begin{array}{l}\hat{\circ} \\
\text { ᄋ̆ } \\
\text { ○. }\end{array}$ \\
\hline 4 & \begin{tabular}{l}
\multirow{2}{N}{} \\
N̦ \\
0
\end{tabular} & $\begin{array}{l}n \\
\text { f } \\
\text { ○ } \\
\stackrel{1}{1}\end{array}$ & $\begin{array}{l}\infty \\
\stackrel{\infty}{\sim} \\
\stackrel{1}{1}\end{array}$ & 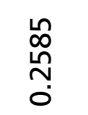 & $\begin{array}{l}\text { 岕 } \\
\text { Oִ } \\
0\end{array}$ & $\begin{array}{l}\hat{N} \\
\text { กิ } \\
0\end{array}$ & 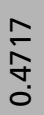 & $\frac{\hat{\infty}}{\stackrel{m}{0}}$ & $\begin{array}{l}\frac{0}{m} \\
\stackrel{m}{+} \\
\stackrel{1}{1}\end{array}$ & $\frac{0}{n}$ & $\frac{\stackrel{ }{\mathcal{Y}}}{\stackrel{+}{+}}$ & $\begin{array}{l}\text { No } \\
\infty \\
\infty \\
0 \\
0\end{array}$ \\
\hline டீ & 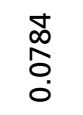 & 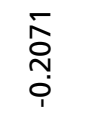 & 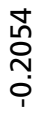 & 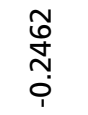 & $\begin{array}{l}\infty \\
\infty \\
\text { O̊ } \\
0 \\
0\end{array}$ & $\begin{array}{l}\frac{m}{\circ} \\
m \\
0\end{array}$ & $\begin{array}{c}\stackrel{0}{\hat{n}} \\
\text { ñ } \\
\text { ò }\end{array}$ & $\frac{\text { જ }}{\text { ○ }}$ & $\begin{array}{l}\stackrel{N}{n} \\
\text { ஸे } \\
0\end{array}$ & $\frac{\hat{n}}{\frac{n}{n}}$ & $\begin{array}{c}\underset{\infty}{+} \\
\underset{m}{m} \\
0 \\
\end{array}$ & 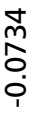 \\
\hline นํㄴ & 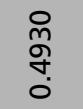 & $\begin{array}{c}\frac{\sigma}{\sigma} \\
\text { ்ֻ } \\
0\end{array}$ & $\begin{array}{l}\infty \\
\stackrel{n}{n} \\
\\
0 \\
\end{array}$ & 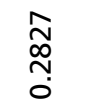 & $\begin{array}{l}\text { m̊ } \\
\text { O্ } \\
\text { o }\end{array}$ & 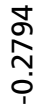 & $\begin{array}{l}\infty \\
\stackrel{\infty}{\infty} \\
\stackrel{0}{0}\end{array}$ & 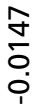 & $\frac{\stackrel{O}{0}}{\stackrel{0}{ \pm}}$ & $\begin{array}{l}\text { の } \\
\text { స్ } \\
\text { ஸ் }\end{array}$ & 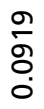 & \\
\hline$\stackrel{+}{\sqcup}$ & $\begin{array}{l}\stackrel{\infty}{\stackrel{N}{N}} \\
\underset{0}{0}\end{array}$ & $\begin{array}{l}\frac{0}{\sigma} \\
\frac{0}{1}\end{array}$ & 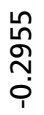 & 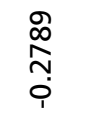 & $\begin{array}{l}\frac{\infty}{m} \\
\text { Ọ } \\
0\end{array}$ & $\frac{0}{0}$ & 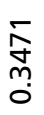 & $\underset{\text { Nָ}}{\text { స̃ }}$ & $\begin{array}{l}\bar{\sigma} \\
\underset{N}{0} \\
0\end{array}$ & 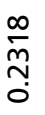 & $\begin{array}{l}\stackrel{0}{0} \\
\text { m. } \\
\dot{0}\end{array}$ & 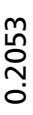 \\
\hline m & $\begin{array}{l}\stackrel{n}{\tilde{O}} \\
\stackrel{0}{0} \\
0\end{array}$ & $\frac{\bar{\infty}}{\stackrel{\infty}{N}}$ & $\frac{\mathbb{Z}}{\stackrel{8}{0}}$ & $\frac{\stackrel{d}{m}}{\frac{1}{i}}$ & 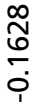 & $\begin{array}{l}\stackrel{0}{0} \\
\text { ஸ̣ } \\
\text { ọ }\end{array}$ & $\begin{array}{l}0 \\
0 \\
\text { ㅇ․ } \\
0\end{array}$ & $\begin{array}{l}\bar{\sigma} \\
\text { Oे } \\
0 \\
\end{array}$ & $\begin{array}{l}\hat{O} \\
\stackrel{+}{+} \\
\stackrel{1}{1}\end{array}$ & 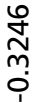 & 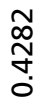 & 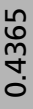 \\
\hline N & $\begin{array}{l}\tilde{m} \\
\text { గ̂ } \\
\stackrel{0}{0}\end{array}$ & $\begin{array}{l}\stackrel{\ln }{0} \\
\stackrel{0}{0} \\
\stackrel{0}{0}\end{array}$ & $\begin{array}{l}\text { no } \\
\text { So } \\
\text { mo } \\
\text { i }\end{array}$ & $\frac{N}{\frac{N}{0}}$ & $\begin{array}{l}\bar{N} \\
\text { ○ } \\
0\end{array}$ & $\begin{array}{l}\text { On } \\
\stackrel{N}{N} \\
\stackrel{1}{i}\end{array}$ & $\begin{array}{c}\infty \\
\stackrel{\infty}{N} \\
\stackrel{N}{0}\end{array}$ & $\frac{\stackrel{m}{m}}{\stackrel{m}{0}}$ & 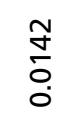 & $\frac{\widetilde{N}}{\underset{0}{0}}$ & $\frac{\text { 웅 }}{0}$ & $\begin{array}{c}\hat{D} \\
\stackrel{\infty}{N} \\
\stackrel{1}{0}\end{array}$ \\
\hline$\overline{4}$ & 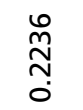 & 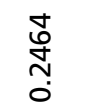 & 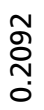 & $\frac{\hat{N}}{\frac{\hat{\sigma}}{0}}$ & $\begin{array}{l}\text { ơ } \\
\text { ஸे } \\
\text { ஸे }\end{array}$ & $\underset{\text { ஸ் }}{\stackrel{0}{0}}$ & $\frac{\stackrel{\operatorname{n}}{\widehat{\sigma}}}{\stackrel{0}{0}}$ & $\begin{array}{l}\text { ऽั } \\
\stackrel{0}{N} \\
0\end{array}$ & 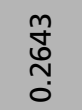 & $\begin{array}{l}\bar{\infty} \\
\underset{N}{N} \\
\tilde{o}\end{array}$ & $\frac{\mathscr{\sigma}}{\stackrel{\sigma}{\sigma}}$ & $\begin{array}{l}\stackrel{n}{0} \\
\stackrel{\infty}{\circ}\end{array}$ \\
\hline 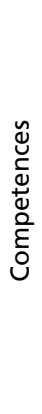 & 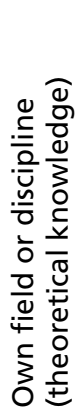 & 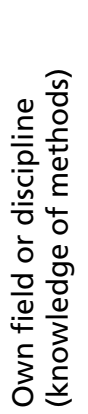 & 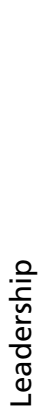 & 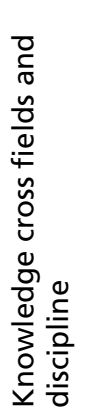 & 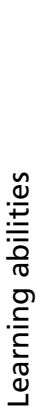 & 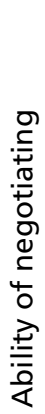 & 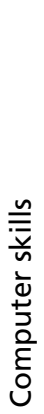 & 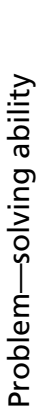 & 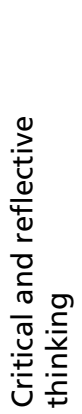 & 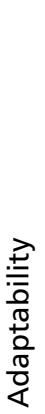 & 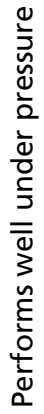 & 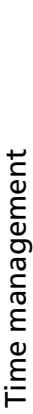 \\
\hline
\end{tabular}




\begin{tabular}{|c|c|c|c|c|c|c|c|}
\hline 운 & 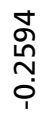 & $\begin{array}{l}\frac{0}{\delta} \\
\text { ma } \\
0\end{array}$ & $\frac{\stackrel{N}{N}}{0}$ & 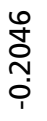 & $\frac{n}{\frac{n}{m}}$ & 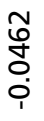 & $\stackrel{n}{\stackrel{n}{N}}$ \\
\hline$\stackrel{\infty}{4}$ & $\begin{array}{l}\stackrel{\infty}{0} \\
\underset{N}{N} \\
\text {. }\end{array}$ & $\begin{array}{l}\bar{N} \\
\text { గ్ } \\
\stackrel{i}{1}\end{array}$ & 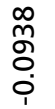 & $\frac{N}{\bar{N}}$ & $\begin{array}{l}\bar{o} \\
\text { ơ } \\
\dot{0}\end{array}$ & $\frac{\text { กิ }}{\frac{m}{0}}$ & 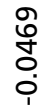 \\
\hline ㄴ. & $\frac{\substack{n \\
m}}{\dot{p}}$ & 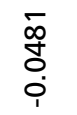 & $\begin{array}{l}\infty \\
0 \\
\text { m } \\
0 \\
0\end{array}$ & $\frac{\infty}{\overleftarrow{\infty}}$ & $\begin{array}{l}\infty \\
\stackrel{\infty}{n} \\
0 \\
0 \\
1\end{array}$ & 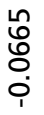 & $\underset{\stackrel{0}{\infty}}{\stackrel{\infty}{0}}$ \\
\hline 인 & $\begin{array}{l}\infty \\
\stackrel{2}{2} \\
\text { ஸे } \\
0\end{array}$ & $\underset{\text { N̦}}{\stackrel{m}{\sigma}}$ & $\begin{array}{l}\text { mo } \\
\text { ஸ̂n } \\
\text { o }\end{array}$ & 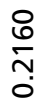 & $\begin{array}{l}\stackrel{+}{0} \\
\stackrel{\text { }}{0} \\
\text { î }\end{array}$ & $\frac{\substack{\infty\\
}}{i}$ & 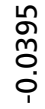 \\
\hline 눈 & 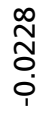 & $\begin{array}{l}0 \\
\infty \\
\stackrel{0}{0} \\
\stackrel{1}{1}\end{array}$ & $\begin{array}{l}\stackrel{\infty}{m} \\
\stackrel{0}{0} \\
\dot{1}\end{array}$ & $\frac{\stackrel{\infty}{n}}{\frac{n}{m}}$ & 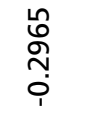 & 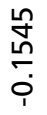 & $\frac{\bar{m}}{\stackrel{0}{0}}$ \\
\hline$\underset{\leftarrow}{\mathbb{*}}$ & $\frac{\stackrel{m}{N}}{\stackrel{m}{0}}$ & 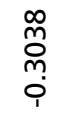 & $\frac{\infty}{\stackrel{\infty}{+}}$ & $\frac{O}{\stackrel{+}{N}}$ & $\begin{array}{l}\infty \\
\infty \\
\wp \\
\stackrel{0}{1}\end{array}$ & $\frac{\stackrel{\infty}{N}}{\stackrel{n}{0}}$ & 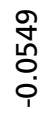 \\
\hline$\underline{m}$ & $\underset{\substack{m \\
0}}{\stackrel{m}{0}}$ & 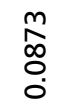 & $\begin{array}{l}\bar{ষ} \\
\text { ○ } \\
\dot{1}\end{array}$ & $\frac{\stackrel{n}{n}}{\frac{1}{0}}$ & 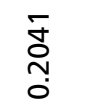 & 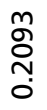 & $\frac{\text { ᄋ }}{\frac{\sigma}{\circ}}$ \\
\hline $\mathbb{N}$ & 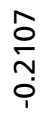 & 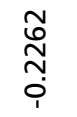 & $\frac{n}{\stackrel{n}{N}}$ & $\begin{array}{l}\stackrel{0}{1} \\
\text { No } \\
0 \\
i\end{array}$ & $\frac{N}{\frac{N}{m}}$ & $\frac{\stackrel{\omega}{\infty}}{\frac{\infty}{\sigma}}$ & $\begin{array}{l}\text { : } \\
\text { ஸे } \\
\text { ণ. }\end{array}$ \\
\hline$\overline{4}$ & \begin{tabular}{l}
$\bar{\sigma}$ \\
\multirow{0}{0}{}
\end{tabular} & 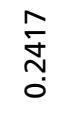 & 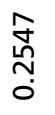 & $\begin{array}{l}\stackrel{\sigma}{\stackrel{N}{n}} \\
0\end{array}$ & $\underset{0}{\stackrel{\nabla}{n}}$ & 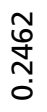 & $\begin{array}{l}\bar{\infty} \\
\stackrel{N}{0} \\
0\end{array}$ \\
\hline 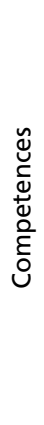 & 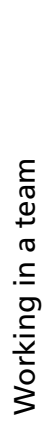 & 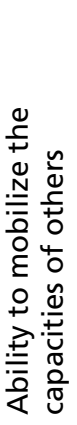 & 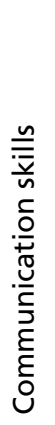 & 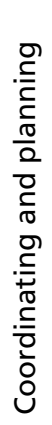 & 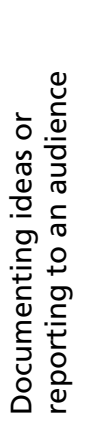 & 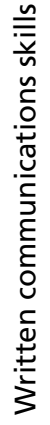 & 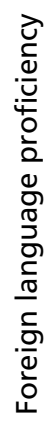 \\
\hline
\end{tabular}

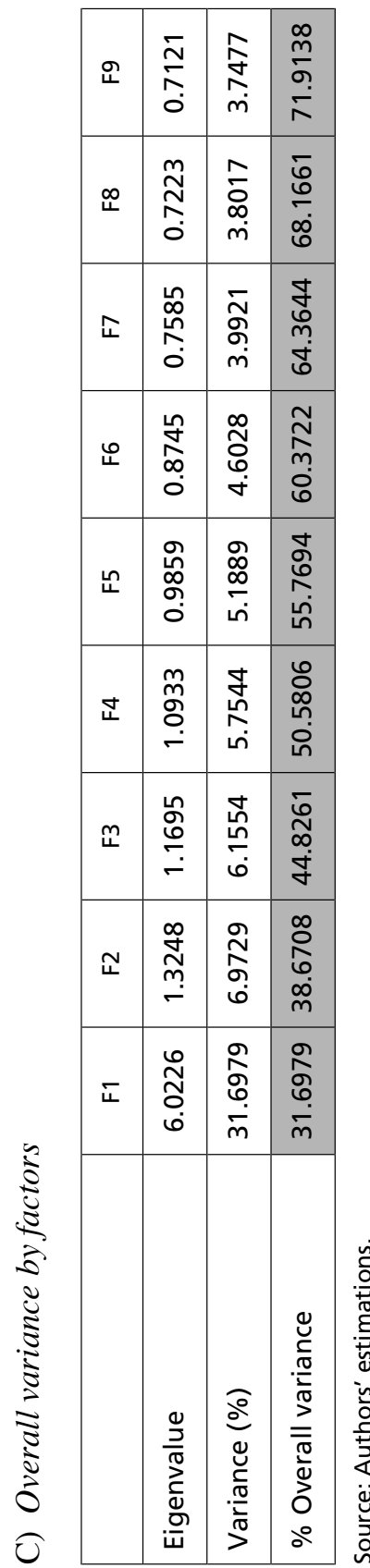

Tuning Journal for Higher Education 
D) Factors and their corresponding competences

\begin{tabular}{|c|c|c|c|c|}
\hline \multirow{2}{*}{$\begin{array}{c}\text { Factor } \\
\text { F1 }\end{array}$} & \multicolumn{4}{|c|}{ Competences } \\
\hline & $\begin{array}{l}\text { Learning } \\
\text { abilities }\end{array}$ & $\begin{array}{l}\text { Critical and } \\
\text { reflective } \\
\text { thinking }\end{array}$ & Adaptability & $\begin{array}{l}\text { Coordinating } \\
\text { and planning }\end{array}$ \\
\hline $\mathrm{F} 2$ & $\begin{array}{l}\text { Documenting } \\
\text { ideas or } \\
\text { reporting to an } \\
\text { audience }\end{array}$ & $\begin{array}{l}\text { Written } \\
\text { communications } \\
\text { skills }\end{array}$ & $\begin{array}{l}\text { Foreign } \\
\text { language } \\
\text { proficiency }\end{array}$ & \\
\hline F3 & $\begin{array}{l}\text { Time } \\
\text { management }\end{array}$ & $\begin{array}{l}\text { Working in a } \\
\text { team }\end{array}$ & & \\
\hline F4 & $\begin{array}{l}\text { Problem-solving } \\
\text { ability }\end{array}$ & & & \\
\hline F5 & $\begin{array}{l}\text { Own field } \\
\text { or discipline } \\
\text { (theoretical } \\
\text { knowledge) }\end{array}$ & $\begin{array}{l}\text { Own field } \\
\text { or discipline } \\
\text { (knowledge of } \\
\text { methods) }\end{array}$ & & \\
\hline F6 & $\begin{array}{l}\text { Communication } \\
\text { skills }\end{array}$ & & & \\
\hline F7 & $\begin{array}{l}\text { Ability to } \\
\text { negotiate }\end{array}$ & Computer skills & & \\
\hline F8 & $\begin{array}{l}\text { Knowledge } \\
\text { cross fields and } \\
\text { discipline }\end{array}$ & & & \\
\hline F9 & Leadership & $\begin{array}{l}\text { Performs well } \\
\text { under pressure }\end{array}$ & $\begin{array}{l}\text { Ability to } \\
\text { mobilise the } \\
\text { capacities of } \\
\text { others }\end{array}$ & \\
\hline
\end{tabular}

Source: Authors' estimations. 
E) Summary statistics (variables of the model)

\begin{tabular}{|l|c|c|c|c|c|}
\hline \multicolumn{1}{|c|}{ Variable } & Observations & Min & Max & Mean & St. Dev \\
\hline Ln(wages) & 1,177 & 5.99 & 10.27 & 8.55 & 0.52 \\
\hline F1 & 1,177 & -15.10 & 3.36 & 0 & 2.45 \\
\hline F2 & 1,177 & -4.80 & 4.29 & 0 & 1.15 \\
\hline F3 & 1,177 & -6.82 & 4.77 & 0 & 1.08 \\
\hline F4 & 1,177 & -4.08 & 3.80 & 0 & 1.05 \\
\hline F5 & 1,177 & -5.13 & 3.82 & 0 & 0.99 \\
\hline F6 & 1,177 & -3.60 & 3.27 & 0 & 0.94 \\
\hline F7 & 1,177 & -3.79 & 3.04 & 0 & 0.87 \\
\hline F8 & 1,177 & -3.04 & 4.08 & 0 & 0.85 \\
\hline F9 & 1,177 & -3.99 & 3.57 & 0 & 0.84 \\
\hline Education in years & 1,177 & 2.00 & 9.00 & 3.87 & 1.11 \\
\hline Age & 1,177 & 19.00 & 58.00 & 29.91 & 6.47 \\
\hline Experience years & 1,177 & 0.08 & 4.33 & 2.15 & 1.12 \\
\hline Female & 1,177 & 0 & 1 & 0.44 & 0.50 \\
\hline Married & 1,177 & 0 & 1 & 0.23 & 0.42 \\
\hline Private sector & 1,177 & 0 & 1 & 0.65 & 0.48 \\
\hline City work & 1,177 & 0 & 1 & 0.79 & 0.41 \\
\hline Major Social & 1,177 & 0 & 1 & 0.59 & 0.49 \\
\hline Open access & 1,177 & 0 & 1 & 0.48 & 0.50 \\
\hline
\end{tabular}

Source: Authors' estimations. 


\begin{tabular}{|c|c|c|c|c|c|c|c|c|c|c|c|c|c|c|c|c|c|c|c|}
\hline 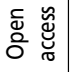 & & & & & & & & & & & & & & & & & & & - \\
\hline 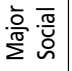 & & & & & & & & & & & & & & & & & & - & 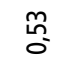 \\
\hline$\vec{E}$ & & & & & & & & & & & & & & & & & - & ஜ웅 & $\frac{N}{0}$ \\
\hline 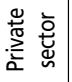 & & & & & & & & & & & & & & & & - & $\frac{1}{0}$ & $\frac{m}{i}$ & $\begin{array}{l}\text { ñ } \\
\stackrel{1}{1}\end{array}$ \\
\hline 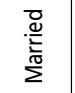 & & & & & & & & & & & & & & & - & $\begin{array}{c}\text { m. } \\
\text { i }\end{array}$ & סo & $\frac{n}{0}$ & $\frac{n}{0}$ \\
\hline 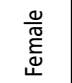 & & & & & & & & & & & & & & - & 客 & ñ & 8 & 농 & mô \\
\hline 这 & & & & & & & & & & & & & - & 흐. & 孚 & $\begin{array}{c}m \\
m \\
i\end{array}$ & $\bar{\sigma}$ & 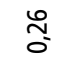 & $\frac{\Delta}{0}$ \\
\hline 㞼 & & & & & & & & & & & & - & $\underset{\tilde{z}}{\sigma}$ & $\frac{N}{0}$ & $\bar{m}$ & స్ & Õ & $\frac{\nabla}{0}$ & $\frac{n}{0}$ \\
\hline 굼 & & & & & & & & & & & - & $\bar{c}$ & ֻू & 웅 & $\frac{\infty}{0}$ & চ & $\frac{n}{0}$ & 옹 & 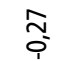 \\
\hline 운 & & & & & & & & & & - & $\tilde{O}$ & 훙 & 능 & 농 & 웅 & 号 & 훙 & E & $\bar{i}$ \\
\hline ळ & & & & & & & & & - & 응 & $\overline{0}$ & 必 & o̊ & 응 & 守 & no & 녕 & ণ̊ & ষ্ণ \\
\hline 4 & & & & & & & & - & 응 & 응 & 응 & 훙 & 官 & $\tilde{O}$ & 응 & 용 & 号 & 능 & $\begin{array}{l}00 \\
\text { : }\end{array}$ \\
\hline 안 & & & & & & & - & 응 & 응 & 응 & O̊ & $\bar{c}$ & 웅 & 灾 & 웅 & 응 & 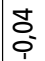 & $\frac{m}{i}$ & $\frac{}{\circ}$ \\
\hline 난 & & & & & & - & 응 & 8 & 응 & 8 & m & 8 & $\begin{array}{l}\text { mo } \\
0 \\
0\end{array}$ & m & 8 & б. & $\bar{\delta}$ & io & ô. \\
\hline ष & & & & & - & 응 & 응 & 응 & 응 & 응 & 응 & $\begin{array}{l}0 \\
0 \\
\end{array}$ & 응 & $\overline{0}$ & $\bar{c}$ & $\overline{\check{g}}$ & 능 & $\begin{array}{l}\text { m } \\
0 \\
\end{array}$ & $\underset{1}{E}$ \\
\hline$\ddot{4}$ & & & & - & 음 & 응 & 응 & 응 & 응 & 응 & 茰 & 命 & 立 & mo & 응 & ষ্ণ & $\begin{array}{l}n \\
0 \\
0 \\
\end{array}$ & ס̊ & $\overline{0}$ \\
\hline ㄴ & & & - & 웅 & 응 & 응 & 응 & 응 & 응 & 응 & $\frac{5}{\sigma}$ & 능 & 足 & 훙 & 志 & $\frac{\Delta}{0}$ & $\bar{\sigma}$ & $\frac{m}{i}$ & $\frac{\infty}{0}$ \\
\hline$\overline{4}$ & & - & 8 & 8 & 8 & 8 & 응 & 8 & 8 & 8 & $\frac{6}{6}$ & 응 & $\frac{7}{0}$ & 侻 & $\frac{n}{0}$ & 농 & $\overline{0}$ & ஜ̊ & ô \\
\hline$\underset{5}{\widehat{s}}$ & - & $\underset{\delta}{\approx}$ & 我 & 훙 & 웅 & 훙 & 电 & $\tilde{O}$ & $\begin{array}{l}\tilde{0} \\
0 \\
\end{array}$ & d & 导 & $\cong$ & $\bar{m}$ & $\frac{m}{c}$ & $\frac{9}{0}$ & $\frac{n}{0}$ & 웅 & $\bar{\sigma}$ & $\frac{m}{i}$ \\
\hline 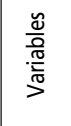 & 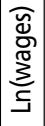 & ㅍ & $\mathbb{2}$ & $\ddot{m}$ & サ & 눈 & 온 & 궁 & 必 & 욤 & 굼 & 芩 & 这 & 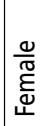 & 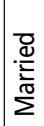 & 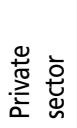 & $\vec{\Xi}$ & $\frac{\overline{\frac{a}{\pi}}}{\frac{\pi}{2} \cdot \frac{\bar{\sigma}}{0}}$ & ळ̋ \\
\hline
\end{tabular}




\title{
An examination of the relationship between competences and wages of higher education graduates: Evidence from Morocco
}

\author{
Abdellah Abaida, Youssef Lakrari, and Abdeljabbar Abdouni
}

\section{Copyright}

Copyright for this article is retained by the Publisher. It is an Open Access material that is free for download, distribution, and or reuse in any medium only for non-commercial purposes; provided any applicable legislation is respected, the original work is properly cited, and any changes to the original are clearly indicated. 